\title{
POTENTIAL INFECTIVITY OF BLOOD FROM HBSAg ASYMPTOMATIC CARRIERS DUE TO THE PRESENCE OF HBV-DNA AND COMPARISON WITH OTHER MARKERS OF HBV INFECTION
}

\author{
M. Valeria TEDESCHI (1), Cláudia Figueiredo PADILLA (1), Iná Ferraz de CAMARGO (2) \&
}

Clara F. Tachibana YOSHIDA (1).

\begin{abstract}
SUMMARY
Serum samples from $356 \mathrm{HBsAg}$ positive asymptomatic carriers, which were titrated by reverse passive hemagglutination, were analysed for the presence of HBV-DNA, HBsAg and IgM anti-HBc. The samples were divided in three classes, according to the titers of $\mathrm{HBSAg}$ and IgM anti-HBC and the distribution of HBV-DNA and HBsAg among these classes was studied. In the high titer class of HBsAg, $65 \%$ of samples have one or both markers against only $19 \%$ in the low titer class. From the total of 356 samples, 121 gave positive results for IgM anti-HBc (33.9\%). From these, $38.9 \%$ of HBV-DNA and $47.9 \%$ of HBeAg were observed, whereas in samples with absence of $\operatorname{IgM}$ anti-HBc, $18.3 \%$ and $16.6 \%$ were respectively found.

A higher frequency of agreement between all these markers was found in the class of high titers of HBsAg; however, HBV-DNA was detected in the low titer class of HBsAg and little or no IgM anti-HBc, showing potential blood infectivity even in HBsAg positive borderline samples.
\end{abstract}

KEY WORDS: HBV-DNA: HBsAg; IgM anti-HBc'Asymptomatic carriers.

\section{INTRODUCTION}

The Hepatitis $B$ virus (HBV) is one of the viruses that cause hepatitis in man, and the clinical picture is extremely variable, causing acute and chronic forms with different prognosis and degrees of severity, including cirrhosis and a strong epidemiological and biochemical eviden ce for association with hepatocellular carcino ma.

The infection is endemic in many parts of the world and in our country it poses a significant problem, with high frequencies of the infec- tion being found in some areas. 12. 29 , mainly in West Amazon where its presence is often associated to the Delta virus ${ }^{3.13}$.

The diagnosis of $\mathrm{HBV}$ infection is usually achieved by assay of the HBV surface antigen (HBsAg) but this marker does not indicate the presence of infectious particles in the blood. In individuals. infected with $\mathrm{HBV}, \mathrm{HBSAg}$ is found predominantly in the form of $22 \mathrm{~nm}$ non-infectious particles and also as part of surface antigen present in complete HBV particles ${ }^{8}$. These com

(1) Departamento de Virologia, Fundação Oswaldo Cruz, Rio de Janeiro, Brazil

(2) Bio-Manguinhos, Fundaçáo Oswaldo Cruz, Rio de Janeiro, Brazil.

Address for correspondence: Dra. M. Valeria Tedeschi, Fundaçāo Oswaldo Cruz, Departamento de Virologia, Av. Brasil 4365. CEP 21040 Rio de Janeiro. RJ, Brazil. 
TEDESCHI. M. V.: PADILLA, C. F.: CAMARGO. I. F. de \& YOSHIDA, C. F. T. - Potential infectivity of blood from HBSAg asymptomatic carriers due to the presence of HBV-DNA and comparison with other markers of $H B V$ infection. Rev. Inst. Med. trop. S. Paulo, 31(6), 337 383, 1989

plete particles also have an inner core which contains the Hepatitis B core antigen ( $\mathrm{HBcAg}$ ) and HBeAg in a cryptic form ${ }^{12}, 31$. The presence of $\mathrm{HBeAg}$ in the serum as a soluble protein is asso ciated with the production of complete virion ${ }^{25}$, and is therefore utilized as a marker of infec tivity.

Inside the core, a double-stranded circular DNA and a virus specific DNA polymerase can be found ${ }^{15}, 16.20$.

Different techniques are available for the de tection of complete virus but they are either of low sensitivity, like electron microscopy, $\mathrm{HBcAg}$ detection and DNA polymerase assay or indirect like the detection of HBeAg.

Recently, the use of molecular hybridization analysis allowed the serological detection of HBV-DNA by nucleic acid hybridization, provi ding a direct and highly sensitive marker of viral replication ${ }^{4}, 5,6.28$

In this work, we sought to establish the po tential infectivity of HBsAg positive sera from asymptomatic carriers as determined by the presence of HBV-DNA. The correlation of HBeAg, IgM anti-HBC and HBsAg levels with HBV-DNA positivity was studied.

\section{MATERIALS AND METHODS}

HBsAg positive serum samples from 356 blood donors of different blood banks from Rio de Janeiro were analysed.

\section{Detection of serological HBV markers}

HBsAg detection - These samples wère confirmed by Elisa - FIOCRUZ ${ }^{7}$ and titrated by R-PHA (Bio-Manguinhos - FIOCRUZ) ${ }^{30}$.

HBeAg detection - HBsAg positive sam ples were tested for the presence of HBeAg using Elisa Kits from Organon as well as reagents produced and standardized in our laboratory ${ }^{19}$.

IgM anti-HBc detection - All samples were tested with reagents standardized in the Centers for Diseases Control, Atlanta, USA, using HBcAg obtained from cloned E. coli Briefly, $125 \mu$ l of goat anti-human IgM ( $\boldsymbol{\mu}$-chain specific, Sigma), diluted in $50 \mathrm{mM}$ carbonate buffer pH 9.6 were coated in polystirene microplates. After over night incubation, the plates were washed 4 times in BSA $(0.5 \%)$ in PBS, and $100 \mu \mathrm{l}$ of diluted samples $\left(2 \times 10^{3}\right.$ in NHS-PBS) were incubated for $1 \mathrm{~h} / 37 \mathrm{C}$. The plates were washed again, $100 \mu \mathrm{l}$ of purified $\mathrm{HBcAg}(50 \mathrm{ng} / \mathrm{ml})$ diluted in $1 \% \mathrm{NHS}$ PBS was added and the reaction was incubated for 1 hour at $37 \mathrm{C}$. After washing the plates, 100 $\boldsymbol{\mu l}$ of rabbit anti-HBc conjugated to peroxidase diluted in $10 \%$ NHS $/ 10 \%$ NRS/PBS were added and incubation proceeded for $1 \mathrm{~h} / 37 \mathrm{C}$. After washing, $100 \mu \mathrm{l}$ of substrate $1.2 \mathrm{ml}$ of $10 \mathrm{X}$ substrate buffer $+10.8 \mathrm{ml}$ distilled water and $0.25 \mathrm{ml}$ of $5 \mathrm{mg}$ TMB $/ \mathrm{ml} \mathrm{DMSO}$ ) were added and after 30 minutes at room temperature, the reaction was stopped with $100 \mu$ l of $4 \mathrm{~N}$ Sulfuric Acid. (The components of $10 \mathrm{X}$ substrate buffer are Sodium Acetate $34.0 \mathrm{~g}$, Citric Acid $0.73 \mathrm{~g}$, in $250 \mathrm{ml}$ of distilled water and $0.3 \mathrm{ml} \mathrm{H}_{2} \mathrm{O}_{2} 30 \%$ ). The reac tion is read at $450 \mathrm{~nm}$. The cut-off value is calculated using the mean negative control +0.1 mean positive control. Negative controls are colourless (extinction around 0.05 ) and positive controls give a colour that is clearly discernible from the negative control.

\section{Preparation of samples and molecular hybri- dization}

The serum samples were treated as described by SCOTTO et al ${ }^{23}$. To $50 \mu$ l of sample, the same volume of $2 \mathrm{M} \mathrm{NaCl}$ was added plus two volumes of $1 \mathrm{M} \mathrm{NaOH}$. Following a 10 minutes incubation at room temperature, the samples were spotted by filtration through a BRL Hybridot onto nitrocellulose filters prewet with $6 \mathrm{X}$ SSC (1X SSC: $0.015 \mathrm{M}$ Na citrate, $0.15 \mathrm{M} \mathrm{NaCl}$, $\mathrm{pH}$ 7.0). Neutralization was carried out by addi tion of $200 \mu \mathrm{l}$ of $0.5 \mathrm{M}$ Tris pH 7.4, 3M NaCl, every five samples. The positive and negative controls added to the filters were treated in the same way.

The filters were prehybridized for $1 \mathrm{~h}$ in a hy bridization mix containing $50 \%$ deionized formamide, $5 \mathrm{X}$ Denhardt solution, $50 \mathrm{mM}$ sodium phospate buffer pH 7.5, $5 \mathrm{X}$ SSC and $100 \mu \mathrm{g} / \mathrm{ml}$ denatured salmon sperm DNA, and then the radioactively labelled probe was added to the hybridization solution at a concentration of $1-2 \mathrm{x}$ $10^{6} \mathrm{cpm} / \mathrm{ml}$. Hybridization was carried out at 
TEDESCHI, M. V.: PADILLA, C. F.: CAMARGO. I. F. de \& YOSHIDA, C. F. T. - Potential infectivity of blood from HBsAg asymptomatic carriers due to the presence of HBV DNA and comparison with other markers of $\mathrm{HBV}$ infection, Rev. Inst. Med. trop. S. Paulo, 31(6), 337-383, 1989.

$37^{\circ} \mathrm{C}$ for $15-18 \mathrm{hs}$, followed by two 20 minutes washes in $2 \mathrm{X} \mathrm{SSC}, 0.1 \% \mathrm{SDS}$ at $65^{\circ} \mathrm{C}$ and two 20 minutes washes in $0.1 \times$ SSC, $0.1 \%$ SDS at $65^{\circ} \mathrm{C}$. the filters were exposed to Sakura $\mathrm{X}$-ray films for $24 \mathrm{hs}$.

The probe used in this work was the plasmid pCP10 which was a gift from Dr. Pierre Tiollais from the Institut Pasteur. This plasmid consists of the vector pBR 322 , containing two copies of the $\mathrm{HBV}$ genome. In some experiments the whole plasmid was used as a probe, whereas in others the HBV-DNA was purified by electroelution from agarose gels. The probe was labelled by nick translation ${ }^{22}$ with ${ }^{32} \mathrm{P}$ to a specific activity of $1-2 \times 10^{7} \mathrm{cpm} / \mu \mathrm{g}$ of DNA. The ${ }^{32} \mathrm{P}$-alphadATP was supplied by Dr. José Carlos Maia, from the University of São Paulo.

\section{RESULTS}

The distribution of 356 samples was analysed according to the hemagglutination titers of HBsAg. The titers varied from $1 / 16$ to greater than $1 / 4096$, of which $28.4 \%$ were high titered, with R-PHA titer greater than $1 / 2048$.

The results of the hybridization tests were evaluated by two independent observers and doubtful cases were repeated. 94 out of 356 serum samples were positive when hybridized to pCP10, as exemplified in Figure 1. As it has been reported that false positive cases may arise, possibly as a result of bacterial contamination during storage ${ }^{10}$, all positive samples were hybridized to pBR322, the vector in which the HBVDNA was cloned. Indeed, out of 94 , ten samples were found to hybridize also to pBR322 and were therefore hybridized to the purified HBV-DNA insert. To ascertain the purity of the insert, pBR322 DNA was also spotted onto the filter, giving a negative result. Five of the ten pBR322 positive samples were shown to be positive also for the cloned HBV-DNA, being therefore included among the $\mathrm{HBV}$ positive samples, which were a total of 90

The serological markers HBV-DNA, HBeAg and IgM anti-HBc detected in the present samples were correlated with the concentration of HBsAg, semi-quantitatively represented by the R-PHA titer, divided in three groups: 106 samples with low titer (under 1/128), 149 samples with intermediate titers ( $1 / 256$ to $1 / 1024$ ) and $101 \mathrm{sam}$ ples with hight titers (over 1/2048). The percen tage of HBV-DNA, HBeAg and IgM anti-HBc in creases as the concentration of HBsAg increases (Table I)

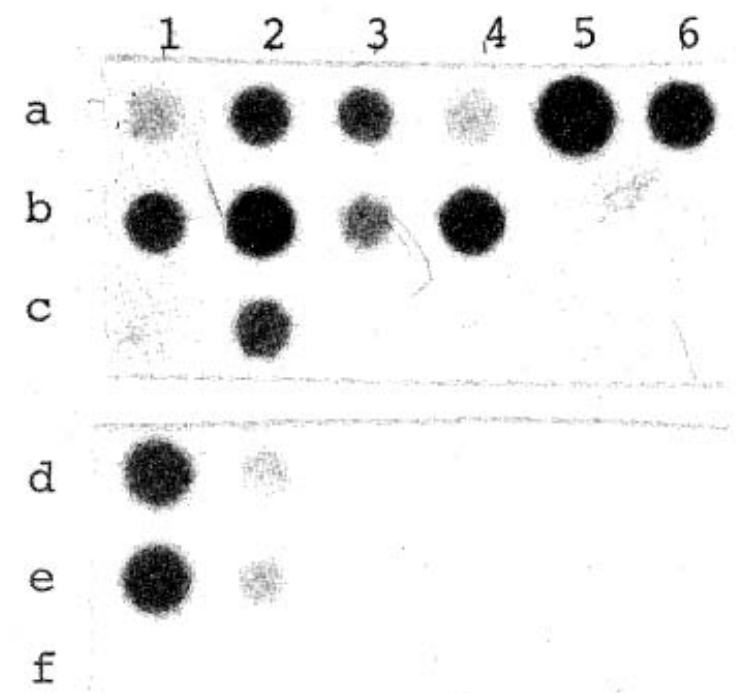

a-1, 2, 3, 4, 5; b-1, 2, 3, 4 and

c-2: positive samples;

b-5, 6 and c-2: negative samples;

a-6: positive control

(purified Dane particles);

d, e and $\mathrm{f}$ : HBV cloned DNA

(purified from pCP10 plasmid);

pCP10 (pBR322 + HBV-DNA)

and pBR322 plasmid DNA,

respectively. On columns 1

through $61000,100,10$ and

$1 \mathrm{pg}$ of DNA were spotted respectively.

Fig. 1-Dot blots of serum of asymptomatic cartiers of HBsAg. using $\mathrm{p}$ CP10 HBV-DNA insert as a probe.

TABLE 1

Correlation between HBV serological markers and hemaggluti nation titer of HBSAg.

\begin{tabular}{cccccc}
\hline $\begin{array}{c}\text { R.PHA* } \\
\text { titer }\end{array}$ & $\begin{array}{c}\text { number } \\
\text { of samples }\end{array}$ & $\begin{array}{c}\text { HBV.DNA } \\
(\%)\end{array}$ & $\begin{array}{c}\text { HBeAg } \\
(\%)\end{array}$ & $\begin{array}{c}\text { IgM } \\
\text { anti.HBC }\end{array}$ \\
\hline under $1: 128$ & 106 & $14(12.3)$ & $10(9.4)$ & $28(26.4)$ \\
\hline $1 / 256$ to 11024 & 149 & $18(12.1)$ & $21(14.1)$ & $52(34.9)$ \\
\hline over 1 2048 & 101 & $58(57.4)$ & $66(65) 3)$ & $41(40.6)$ \\
\hline Total & 356 & $90(25.0)$ & $97(27.2)$ & $121(33.9)$ \\
\hline
\end{tabular}

R-PHA = reverse passive hemagglutination 
TEDESCHI, M. V.; PADILLA. C. F.: CAMARGO. I. F. de \& YOSHIDA. C. F. T. - Potential infectivity of blood from HBSAg asymptomatic carriers due to the presence of HBV DNA and comparison with other markers of HBV infection. Rev. Inst. Med. trop. S. Paulo, 31/6), 337-383, 1989

A clear result can be observed when the per centage of HBV-DNA and/or HBeAg markers is correlated with the titer of HBsAg. In high titer samples $65 \%$ have one or both of these markers against only $19 \%$ in low titer samples (Figure 2).
HBs Ag

\section{R-PHA *UNDER $1 / 128$ LOW TITER \\ $N=106$}

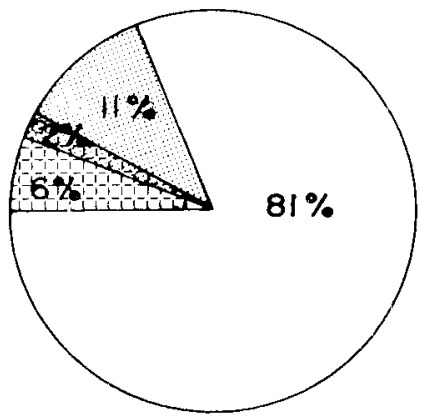

\section{$H B=A g$}
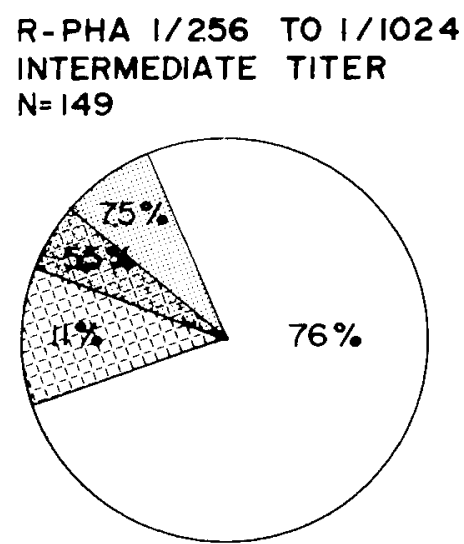

HBs Ag

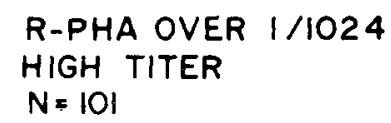

$N=101$

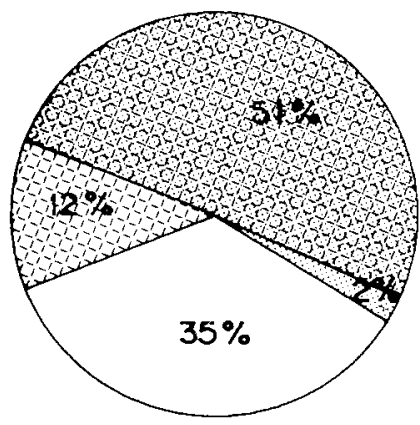

HBV-DNA

HBeAg

\section{*R-PHA: REVERSE PASSIVE HEMAGgLUTINATION TITER OF HBSAg}

Fig. 2 - Percentage of HBV DNA and or HBCAg markers of HBV infection in relation to HBsAg hemagglutination titer.

TABLE 2

Correlation of anti HBc IgM antibodies with HBV DNA and HBeAg serological markers of $\mathrm{HBV}$ infection

\begin{tabular}{ccrr}
\hline IgM anti HBe & $\begin{array}{c}\text { number of } \\
\text { samples }\end{array}$ & HBV DNA $\%$ & HBeAg( : \\
\hline NEG & 235 & $43(18.3)$ & $39(16.6)$ \\
P N 10 & 90 & $34(37.7)$ & $39(59.2)$ \\
P N 1150 & 27 & $10(37.1)$ & $16(59.2)$ \\
P N $\because 50$ & 4 & $3(75.0)$ & $3(75.0)$ \\
& 356 & $90(25.2)$ & $97(27.2)$ \\
\hline
\end{tabular}

P: N: OD sample OD negative in Elisa.

Table 2 shows the correlation of IgM anti $\mathrm{HBC}$ antibodies with $\mathrm{HBV}-\mathrm{DNA}$ and $\mathrm{HBeAg}$. From the total of 356 samples, 121 gave positive results for IgM anti-HBc (33.9\%). In samples with $\mathrm{P} / \mathrm{N}$ less than 10 (weakly positive) and between 11-50, approximately the same presence of HBVDNA and $\mathrm{HBeAg}$ was seen $(37 \%$ and $59 \%$ respec tively). It is important to notice that in samples without IgM anti-HBc marker, $18.3 \%$ of $\mathrm{HBV}$ DNA and $16.6 \%$ of HBeAg were observed, sho- wing that except for strongly positive samples, the presence of $\operatorname{Ig} \mathrm{M}$ anti-HBc seems to be independent of the presence of either HBV-DNA or HBeAg blood infectivity markers in asymptomatic carriers.

\section{DISCUSSION}

Less sensitive methods for the detection of HBsAg, like hemagglutination, are a useful tool to measure the level of antigen present in blood specimens. In sera of asymptomatic carriers of HBsAg, screened from blood donors, a wide va riation of titers was found. It was expected that in specimens with a high concentration of $\mathrm{HBsAg}$, other markers of viral replication, specifically HBV particles, would also be present.

The detection of IgM anti-HBc antibodies was also carried out to compare HBV-DNA and HBeAg markers of infectivity, once it could be associated with viral replication.

Indeed, observing Figure 2, it can be seen that the presence of either $\mathrm{HBeAg}$ and $\mathrm{HBV}$. 
TEDESCHI, M. V.; PADILLA, C. F.; CAMARGO, I. F. de \& YOSHIDA, C. F. T. - Potential infectivity of blood from HBSAg asymptomatic carriers due to the presence of HBV DNA and comparison with other markers of HBV infection. Rev. Inst. Med. trop. S. Paulo, 31/6), 337-383, 1989.

DNA increases in the group with higher titers of HBsAg. In this group (over 1/1024) there is a very high association of HBV-DNA and HBeAg, similar to levels described in the literature. In this class, $96 \%$ of HBV-DNA positive sera are also positive for $\mathrm{HBeAg}$, whereas among the total number of $\mathrm{HBeAg}$ positive cases, only $81 \%$ showed a positive signal for HBV-DNA. This is in agreement with the findings of other authors ${ }^{18}$. ${ }^{23,} 27$ and might be explained, according to TAKAHASHI et al. ${ }^{26}$, by the association of HBeAg with immunoglobulin $G$ causing a lower clearance rate.

This correlation is much decreased among the intermediate titers of $\mathrm{HBSAg}$, although the tendency for higher proportions of HBV-DNA negative/HBeAg positive individuals is maintained. Among the low and intermediate titers of IgM anti-HBC (Table 2), the percentage of individuals carrying $\mathrm{HBeAg}$ is also consistently higher than that of HBV-DNA positive cases. However, this is no longer true for the group of individuals with very low titer of HBsAg (Fig. 1), where a relatively high number of cases, $11 \%$, was found which were positive for HBV-DNA while negative for HBeAg and yet some of them showed a very strong hybridization signal. This observation reinforces the current idea that $\mathrm{HBeAg}$ is not a very good marker of $\mathrm{HBV}$ replication ${ }^{18}$. $\mathrm{Re}$ garding IgM anti-HBc, only three out of these 11 sera were positive for this marker and they were only weakly positive. The same trend is again observed in the group of individuals negative for IgM anti-HBc: although for a slight margin, carriers of HBV-DNA are more frequent than HBeAg positive ones. The explanation for this kind of situation is not known. Judging from the markers we have, it would appear that there is a considerable level of viral genome replication, coexisting with a low expression of viral antigens. It would be interesting to have also the HBcAg status of these samples.

IgM anti-HBc was detected in $33.9 \%$ of the samples but only $25.6 \%$ of them represent a considerable titer of antibodies. The great majority showed a low titer, with $\mathrm{P} / \mathrm{N}$ less than 10 . ROGGENDORF et al. ${ }^{21}$ found the same prevalence in healthy carriers, while other authors reported much higher numbers, such as $75 \%, 81 \%$ and $82 \%{ }^{11.14 .17}$. This apparent discrepancy might be due to a higher cut-off value employed by us, since inspection of the above mentioned papers shows that a great proportion of the reported titer is low, if compared to those found in acute or chronic hepatitis

This profile of IgM anti-HBc is commonly found in blood donors, who are routinely screen ed for clinically inapparent $\mathrm{HBV}$ infection, by the presence of HBsAg. Usually, in these cases, the presence of $\operatorname{IgM}$ anti-HBc is more likely to represent a residual marker from an earlier infec tion than an actual marker of replication, as it can be found in acute cases, where it is often observed in very high titer. It is also worth noti cing that in these latter cases, the titer of $\operatorname{IgM}$ anti-HBc is likely to decrease sharply, while it has been demonstrated that in chronic cases mo derate titers are found, which decrease slowly and persist for a very long time ${ }^{9}{ }^{14}$. In our sam ples, high positivity for IgM anti-HBc was found in only 4 out of 121 cases (13.3\%) and 3 of them were also positive for HBV-DNA and $\mathrm{HBeAg}$, in dicating a situation similar to an early stage of $\mathrm{HBV}$ infection. Thus, it appears that when this antibody is found in very high titers (in this work, the class represented by $\mathrm{P} / \mathrm{N}>50$ ), it might be regarded as an indicator of viral replication. $\mathrm{Ho}$ wever, in groups which show intermediate or low positivity for IgM anti-HBc, the frequency of the other markers associated t 6 HBV replication is moderate and very similar. This indicates that in the majority of blood donors, where IgM anti$\mathrm{HBc}$ is present in medium to low titers, it cannot be associated to viral replication and should be considered just an evidence of a past infection.

Regarding our data as a whole, it can be seen that there are many cases in which HBV DNA is present, even in groups with very low levels of HBsAg and little or no IgM anti-HBc, showing that bordeline positivity for HBsAg can mean potential blood infectivity. Therefore, whenever possible, it is better to screen blood donors for markers of Hepatitis B by a more sensitivity assay, like ELISA, which in the case of HBSAg has the ability to detect up to 5.10 nano grams of antigen?

\section{RESUMO}

Potencial de infectividade em sangue de portadores assintomáticos de HBsAg caracterizado pela presença de HBV-DNA e comparaçáo com outros marcadores da Hepatite $B$. 
TEDESCHI. M. V.: PADILLA, C. F.; CAMARGO, I. F. de \& YOSHIDA, C. F. T. - Potential infectivity of blood from HBsAg asymptomatic carriers due to the presence of HBV DNA and comparison with other markers of HBV infection Rev. Inst. Med. trop. S. Paulo, 31(6),337 383, 1989

Em 356 soros HBsAg positivos de portadores assintomáticos, titulados por hemaglutinação passiva reversa, foi analisada a presença de HBV-DNA, HBeAg e IgM anti-HBc, da seguinte forma: as amostras foram divididas em trés classes de acordo com o título de HBsAg e IgM anti-HBc e foi verificada a distribuiçāo de HBV DNA e HBsAg nestas classes.

Em amostras com títulos elevados de HBsAg, $65 \%$ das amostras tiveram um ou ambos os marcadores HBV.DNA e HBsAg e as mesmas foram encontradas em apenas $19 \%$ das amostras com baixo título de HBsAg. Do total de 356 amostras, 121 foram positivas para IgM antiHBc $(33.9 \%)$. Destas, $38.9 \%$ de HBV-DNA e $47.9 \%$ de HBeAg foram observadas, ao passo que em amostras com ausência de IgM anti-HBc, $18.3 \%$ e $16.6 \%$ foram respectivamente encontrados.

A concordância entre os três marcadores foi encontrada em amostras com alto título de HBsAg, entretanto HBV-DNA foi também detectado em grupo de baixo título de HBsAg na ausência de IgM anti-HBc ou em níveis baixos, mostrando o potencial de infectividade mesmo em amostras de HBsAg com valores próximos ao limite da positividade.

\section{ACKNOWLEDGEMENTS}

The authors gratefully acknowledge Messias da Silva, Luiz Antonio C. Mercadante and Sergio da Silva e Mouta Jr. for technical assistance. Claudia F. Padilla was a trainee in our Depart. ment with a fellowship from CNPq.

Part of this work was supported by CNPq, grant number 40.0081.89.0.

\section{REFERENCES}

1. ALMEIDA, J. D; RUBINSTEIN, D. \& STOTT, E. J. New antigen antibody system in Australia antigen posi tive hepatitis. Lancet, 2: 1225-1227, 1971.

2. BENSABATH G.: HADLER, S. C.: PEREIRA SOARES M. C.; FIELDS, H. \& MAYNARD, J. E. - Epidemiologic and serologic studies of acute viral hepatitis in Brazil's Amazon Basin. Bull. Pan Amer. Hlth. Org., 21: 16-27. 1987

3. BENSABATH, G.; HADLER, S. C.: PEREIRA SOARES M. C.; FIELDS, H.; DIAS. L. B.; POPPER, H. \& MAY NARD. J. - Hepatitis Delta virus infection and Labrea Hepatitis prevalence and role in fulminant Hepatitis in the Amazon Basin. J. Amer. med. Ass., 258: 479-483, 1987
4. BERNINGER, M.; HAMMER, M.; HOYER, B. \& GERIN, J. -- An assay for the detection of the DNA genome of Hepatitis B virus in serum. J. med. Virol, 9: 57-68, 1982.

5. BRECHOT, C. \& HADCHOUEL, M. SCOTTO, J.: DE GOS, F.; CHARNAY, P.; TREPO, C. \& TIOLLAIS, P. Detection of Hepatitis $B$ virus DNA in liver and serum: A direct appraisal of the chronic carrier state. Lancet, 2: 765.768 .1981

6. BONINO, F ; HOYER, B.; NELSON, J.; ENGLE, R.; VER ME, G. \& GERIN, J. - Hepatitis B virus DNA in the sera of the HBsAg carriers: a marker of active hepatitis $B$ virus replication in the liver. Hepatology, 1: 386-391. 1981.

7. CAMARGO, I. F.: GASPAR. A. M. C. \& YOSHIDA, C F. T. - Comparative ELISA reagents for detection of Hepatitis B surface antigen (HBsAg). Mem. Inst. Oswaldo Cruz, 82: 181-187, 1987

8. DANE, D. S.; CAMEROM, C. H. \& BRIGGS, M. - Virus like particles in serum of patients with Australia antigen associated hepatitis. Lancet, 1: 695-698, 1970.

9. DEINHARDT, F. - Predictive value of markers of Hepatitis virus infection. $\mathbf{J}$. infect. Dis., 141: 299 305, 1980.

10. DIEGUTIS, P. S.; BURNETT, L.; NIGHTINGALE, B. N ; LOWE, S. B.; GIUNEY, R. C.; COSSART, Y. E.; KEIR NAN, E.; WILLIANS, G.; PARSONS, C.; MCCAUGHAN, G.: FREIMAN, J.: BRITTON, W, J. \& GALLAGER, N D. - Relationship between hepatitis B virus DNA in blood and serological markers of hepatitis $B$ infection. Med. $J$. Aust., 144: 351-355, 1986 .

11. DORMEYER, H. H.; ARNOLD, W.; KRYGER, P.; NIEL SEN, J. O. \& MEYER ZUM BUSCHENFELDE, K. H. IgM antibody to hepatitis B core antigen (anti HBc IgM) in "healthy" HBsAg carriers: A longitudinal study of 75 cares. Klin. Wschr., 59: 675-678, 1981

12. FAY, O. H ; HADLER, S C.; MAYNARD, J.E. \& PINHEI RO, F. - Hepatitis in the Americas. Bol. epidem. (OPS), 6(5): $1-7,1985$.

13. FIGUEIREDO MENDES, F; SIMONETTI, J P ; FONSECA, J. C. F.; SIMONETTI, S. R. R.; PITELLA, A. M. SCHATZMAYR, H. G.: LIMA FERREIRA, L. C.: MIRAN DA SANTOS, I. K : MEXAS, P. P. F. \& HERBERT, B A. - O impacto da hepatite Delta. Mod. Hepat., 9: 16-22, 1984

14. GERLICH, W. H ; LUER, W ; THOMSSEN, R. \& the study group for viral hepatitis of the Deutsche Forschungsge meinchaft. - Diagnosis of acute and inapparent hepatitis $B$ virus infections by measurement of IgM antibody to hepatitis B core antigen. J. infect. Dis., 142: 95-101, 1980.

15. KAPLAN, P. M.; FORD. E. C.; PURCELL, R. H. \& GERIN J. L. - Demonstration of subpopulation of Dane particles. J. Virol., 17: 885893,1976 .

16. KAPLAN, P. M.: GREENMAN, R. L.: GERIN, J. L.; PUR CELL, R. H. \& ROBINSON, W. S. - DNA polymerase associated with human hepatitis $B$ antigen. J. Virol., 12: $995-1005,1973$

17. KRYGER, P.: MATHIESEN, L. R.: ALDERSHVILE, J. \& NIELSEN, J. O. - Presence and meaning of anti. HBC IgM as determined by ELISA in patients with acute type $B$ hepatitis and healthy HBsAg carriers. Hepatology, 12: $50.53,1982$.

18. MATSUYAMA, Y; OMATA, M.; YOKOSUKA, O.; IMA. ZEKI, F, ITO, Y \& OKUDA, K. - Discordance of Hepatitis B e Antigen/Antibody and Hepatitis B Virus Deoxyri bonucleic Acid in serum. Gastroenterology, 89: 1104-1108, 1985 
TEDESCHI, M. V.: PADILlA, C. F.: CAMARGO, I. F. de \& YOSHIDA, C. F. T. - Potential infectivity of blood from HBsAg asymptomatic carriers due to the presence of HBV DNA and comparison with other markers of HBV infection Rev. Inst. Med. trop. S. Paulo, 31(6), 337-383, 1989.

19. MERCADANTE, L. A. C.: ENNES, I. C.: GASPAR, A. M. C. \& YOSHIDA, C. F. T. - An enzyme immunoassay for the detection of hepatitis e antigen and its antibody. In: ENCONTRO NACIONAL DE VIROLOGIA, 3., Sảo Lourenço, MG, 1986. Resumos p. 36.

20. ROBINSON, W. S. \& GREENMAN, R. L. - DNA polymerase in the core of the hepatitis $B$ virus candidate. J. Virol., 13: $1231-1236,1974$

21. ROGGENDORF, M.; DEINHARDI, F.; FROSNER, G. G.; SCHEID, R.: BAYERL, B. \& ZACHOUVAL, R. - Immunoglobulin $\mathrm{M}$ antibodies to hepatitis $\mathrm{B}$ core antigen: evo. lution of enzyme immunoassay for diagnosis of hepatitis $B$ virus infection. J. clin. Microbiol., 13: 618-626, 1981.

22. RIGBY, P. W. I.; DIECKMANN, M.; RHODES, C. \& BERG, P. - Labelling deoxynucleic acid to high specific activity in vitro by niek translation with DNA polymerase. J. molec. Biol., 113: $237-251,1977$.

23. SCOTTO, J.; HADCHOVEL, M.; HERY, C.: YUART, J.; TIOLLAIS, P. \& BRECHOT, C. - Detection of hepatitis $B$ virus DNA in serum by a simple spot hybridization tech. nique: comparison with results of other viral markers. Hepatology, 3: 279.284, 1983

24. TAKAHASHI, $\mathrm{K}$; AKAHANE, Y.; GO'TANDA, T.: MI SHIRO $T$. IMAI $M$. MIYAKAWA, $\mathrm{Y}$ \& MAYUMI $M$ - Demonstration of hepatitis B e antigen in the core of Dane particles. J. Immunol., 122: 275-279, 1979

25. TAKAHASHI, K, IMAI, M : TSUDA, F.: TAKAHASHI T.: MIYAKAWA, Y.\& MAYUMI, M. - Association of Dane particles with $\mathrm{e}$ antigen in the serum of asymptomatic carriers of hepatitis surface antigen. J. Immunol, 117. $102 \cdot 105,1976$.

26. TAKAHASHI, K.; MIYAKAWA, Y.; GOTANDA, T.; MI SHIRO, T.; IMAI, M. \& MAYUMI, M. - shift from "small" Hepatitis B e Antigen to IgG-bound "large" form in the circulation of human beings and chimpanzee acutely in fected with Hepatitis B Virus. Gastroenterology, 77 $1193-1199,1979$

27. THIERS $\mathrm{V}$ : BOUCHARDEAU, $\mathrm{F}$ : COUROUCE A $\mathrm{M}$ TIOLLAIS, P. \& BRECHO'T, C. - L'ADN du virus d l'hepatite $B$ comme marqueur de multiplication virale comparison avec l'antigène HBe et l'anticorps anti.HBe Presse méd., 15: 1219-1222, 1986.

28. WELLER, I. V. D.; FOWLER, M. J. F.: MONJARDINO J. \& THOMAS, H. C. - The detection of HBV DNA in serum by molecular hybridization: A more sensitive me thod for the detection of complete HBV particles. J. med. Virol, 9:273-280, 1982.

29. YOSHIDA, C. F T : MERCADANTE L A C : GASPAR A. M. C.: GOMES, D. F. D. L. \& SCHATZMAYR, H. G - Identification of an endemic area to HBV (hepatitis $B$ virus) infection in a rural population of the south east of Brazil. Hepatitis Seientific Memoranda: 32 34, March 1986 .

30. YOSHIDA, C. F. T.; MERCADANTE, L, A. C.; GASPAR, A. M. C.: MAIA, M. M. S.: BERR, O. J.: ALMEIDA, E C. C. \& SCHATZMAYR, H. G. - Anticorpos anti HB obtidos em coelhos e sua utilizaçào como reagentes para testes sorológicos no diagnóstico da Hepatite B. Mem Inst. Oswaldo Cruz, 79: $329 \cdot 336,1984$.

31. YOSHIZAWA, H.; ITOH, Y.: SIMONETTI, J. P.: TAKA HASHI, T.; MACHIDA, A.; MIYAKAWA, Y. \& MAYUMI M. - Demonstration of hepatitis $B$ e antigen in hepatitis $B$ core particles obtained from the nucleus of hepatocytes infected with hepatitis B virus. J. gen. Virol., 42: 513519 1979 .

Recebido para publicaçào em 16/5/1989 